\title{
Population growth of Varroa jacobsoni Oud in Mediterranean climates of California
}

\author{
B Kraus *, RE Page Jr \\ Department of Entomology, UC Davis, Davis, CA 95616, USA
}

(Received 1st November 1994; accepted 3 February 1994)

\begin{abstract}
Summary - In April and October mite-free honey-bee colonies were artificially infested with 50 individuals of Varroa jacobsoni each and treated with the pesticide Apistan ${ }^{(B)}$ after a period of 24 weeks. Population growth was studied in 24 colonies from April to October and in 6 colonies from October to April. The proportion of Varroa jacobsoni that invaded the test colonies after the initial inoculation was monitored in colonies that were constantly treated with Apistan ${ }^{\oplus}$. Conservative calculations suggested that the initial mite population in a honey-bee colony increases on average about 300 -fold during 1 year in central California. This result excludes the contribution of additional mites that invaded the colonies. The result of the present study demonstrates the high virulence of Varroa jacobsoni in California, where beekeepers are forced to treat infested colonies twice a year.
\end{abstract}

Varroa jacobsoni / population dynamics / virulence / Mediterranean climate / California

\section{INTRODUCTION}

The population growth and virulence of the honey-bee parasite Varroa jacobsoni depend on numerous factors. The most obvious ones are race and strain of the bee (Moritz and Hänel, 1984; Büchler, 1990; Rosenkranz, 1990; Fuchs, 1991; Moretto et al, 1991; Otten, 1991; Kulincevic et al, 1992, etc), climate (De Jong et al, 1984; Ritter and De Jong, 1984; Moretto et al, 1991, etc) and possibly Varroa biotype (Delfinado-Baker and Houck, 1989). In cold and temperate climates, the number of mites increases about 10-fold per year and infested colonies collapse after about 4 years (Ritter, 1984; Fries et al, 1991; Korpela et al, 1992). In tropical climates the parasite seems to be less virulent (Ritter and De Jong, 1984; Engels et al, 1986; Rosenkranz, 1990). From countries with Mediterranean climates, high population growths and increased virulence of $V$ jacobsoni have been reported (Lubinevski et al, 1988; Frilli, 1989). In particular, the question whether we are always dealing with the same mite

* Present address: Universiteit Utrecht, Vakgroep Vergelijkende Fysiologie Projectgroep Ethologie en Socio-oecologie, Centrumgebouw Noord 2 Padualaan 14, De Uithof, Postbus 80086, NL-3508 TB Utrecht, The Netherlands. 
biotype has not yet been answered. The parasite was most likely imported into South America in 1971 from Japan (De Jong et al, 1982). The results of a study conducted by Delfinado-Baker and Houck (1989) suggest that $V$ jacobsoni spread from South America to the USA where it was detected in 1987. An alternative hypothesis is that is was imported illegally from Europe by beekeepers. Delfinado-Baker and Houck (1989) suggested a lower virulence of mites from North America compared to mites from Europe on the basis of the hypothesis of a South American origin of mites in the USA.

The objective of the present study was to determine population growth of $V$ jacobsoni in Mediterranean climates of California 1 year after the massive Varroa-induced losses of commercial and feral honey-bee colonies started to occur.

\section{MATERIALS AND METHODS}

\section{Study conducted from April to October 1993}

Tests were conducted with Apis mellifera $\mathrm{L}$ and with Varroa mites collected from this species. Tests were conducted for a 24-week period from Aprii to October 1993. Colonies were compared for the number of Varroa mites, the number of bees, the size of the brood area and the amount of pollen and honey.

\section{Production of colonies with similar Varroa mite infestation levels}

Twenty-four packages of bees $(1 \mathrm{~kg}$ bees per package) were established with naturally mated sister queens. Each package was treated with one Apistan ${ }^{(1)}$ strip (10\% fluvalinate) on April 14 1993 (Herbert et al, 1989). After 5 d, the Apis$\tan$ strips were removed and the packages were installed into single chamber Langstroth-hives containing comb foundation. Two weeks later, each colony was inoculated with 50 female Varroa mites. Fifty young workers were removed from a brood comb and kept in a queen cage. Varroa mites sampled from a highly infested colony were removed from their host bees with a paint brush and transferred through the mesh wire of the queen cage to workers. The inoculation of the bees was conducted at $32^{\circ} \mathrm{C}$ and $55 \%$ relative humidity. The bees and the 50 mites were returned to their colony in queen cages, with sugar.

The bees were treated in a package to prevent contact of the Apistan ${ }^{(\mathbb{R})}$ strips with wax. Residues of fluvalinate in wax might kill the Varroa mites after the initial inoculation (Moosbeckhofer, 1991). The period of 2 weeks between Apistan ${ }^{(B)}$ treatment and inoculation was chosen to prevent the same effect caused by traces of fluvalinate on bees.

\section{Test groups, management of colonies and colony estimates}

Colonies were positioned in groups of 4 . The groups were separated by 5 colonies permanently treated with Apistan that served as monitor colonies to document the transfer of Varroa mites between colonies. The entrances of all colonies were reduced to a width of $5-7 \mathrm{~cm}$ to prevent a mass transfer of Varroa mites by robbing (Sakofski et al, 1990). Ten colonies were treated with vegetable shortening patties (mixture of powdered sugar, drivert sugar (consisting of $92 \%$ sucrose $+8 \%$ invert sugar), sugar and Crisco ${ }^{\oplus 8}$ shortening) to test the effect of vegetable oil on population growth of $V$ jacobsoni. Eleven colonies were maintained without vegetable shortening patties. Data obtained from treated colonies were used in the present study because vegetable shortening patties had no clear influence upon population growth of the parasite (Kraus and Page, 1995).

After becoming established in the middle of April, the colonies were fed continuously until the start of the nectar flow at the end of May. Colonies were maintained in a single story with a standard depth of $24.4 \mathrm{~cm}$. Colonies were checked weekly for eggs and larvae to detect broodless periods, because Varroa mites only reproduce in brood cells. During the nectar flow, honey was extracted from broodless combs, if necessary, to provide space for brood rearing

From 8-11 October, the number of bees, the amount of brood, the amount of pollen, and the 
amount of honey per colony were estimated following the method described by Gerig (1983).

\section{Varroa mite counts}

The hives were provided with a removable bottom board. In monitor colonies and artificially infested colonies, the number of dead mites was counted weekly. After 20 weeks (September 13, 1993; March 10, 1994) the test colonies were treated with Apistan ${ }^{\oplus}$ for $28 \mathrm{~d}$ and the number of dead Varroa mites was counted.

\section{Calculation of population growth}

Given a population size $N_{0}$ of 50 mites and a population size $N_{f}$ at the time $t$, determined by counting dead mites after treatment with fluvalinate, the intrinsic rate of population increase $r$ is determined as follows (Carey, 1993).

$$
\begin{gathered}
r=\ln \left(N_{t} / N_{0}\right) \\
\text { increase } R=\mathrm{e}^{r}
\end{gathered}
$$

To estimate the impact of invading mites on population growth, the average number of mites $N_{\text {, }}$ that invaded the monitor colonies during period $p_{i}$ was added to the calculated number of mites before adding period $p_{i}+1$ in the calculation. The number of Varroa mites $N_{t}$ at a time $t$ (with $t$ consisting of $n$ periods with a length of time $p$ ) and with an average number of mites $N_{j}$ invading the monitor colonies during period $p_{i}$ was calculated as:

$$
N_{t}=\sum_{i=1}^{n} N_{i-1} \times r_{p}+N I_{i}
$$

$N_{i}$ is the total number of Varroa mites in a colony at the end of period $p_{j}$. The factor $r$ was determined by iterative comparison of results of calculations using different values of $r$ with the value of $N_{t}$ actually found.

\section{Study conducted from October 1993 to April 1994}

Population growth of $V$ jacobsoni was studied in 6 colonies from October to April. In 4 colonies, the combs that had direct contact with Apistan strips during the previous treatment were removed and replaced by new combs prior to inoculation. In 2 colonies the combs that had direct contact with the pesticide were not removed prior to inoculation. Fifteen days after finishing the final Apis$\tan ^{\circledR}$ treatment during the study conducted from April to October 1993, 6 colonies were inoculated again with 50 mites each on October 22, as described above. Colonies were positioned in a row. To monitor invasion levels, data were used from all 5 monitor colonies located within the apiary. The entrances of the colonies remained reduced to a width of $5-7 \mathrm{~cm}$. Colonies were maintained in a single story with a standard depth of $24.4 \mathrm{~cm}$. Stored honey was not extracted and the colonies were not provided with additional food. Besides differences mentioned above, the study was conducted as described in part one.

\section{RESULTS}

\section{Mite populations at test end and levels of mite invasion measured in monitor colonies}

At the end of the study conducted from May 1 st to October 7 , test colonies contained an average number of $1614 \pm 485 \mathrm{SE}$ (range = $690-2867, n=21$ ) mites. At the end of the study conducted from October 221993 to April 7 1994, colonies contained an average number of $1268 \pm 316 \mathrm{SE}$ (range = 854-1 620, $n=4$ ). Data obtained from 2 colonies with combs that had direct contact with Apistan ${ }^{(\Theta)}$ strips prior to reinoculation with mites, were not included since mite populations in those colonies were found to be clearly lower than in other test colonies.

\section{Calculation of population growth}

The study conducted from May 1st to October 71993 resulted in an intrinsic rate of increase per week of $r_{7}=1.16$. The study conducted from October 221993 to April 7 1994 resulted in an intrinsic rate of increase 
per week of $r_{7}=1.14$. Given these intrinsic rates of increase the mite population would increase within 1 year 2 248-fold and 910fold, respectively. Given an intrinsic rate of increase of $r_{7}=1.14$ during the winter 6 months and $a$ intrinsic rate of increase of $r_{7}=1.16$ during the summer 6 months, the mite population increases 1430 -fold within 1 year.

During the 24 weeks period between artifical inoculation of the colonies with mites and Apistan ${ }^{(i)}$ treatment on average 186 (summer) and 219 (winter) Varroa mites entered the monitor colonies (fig 1). To take these mites in account, we calculated population growth based on the assumption that all mites that invaded monitor colonies or artificially infested colonies originated from colonies not participating in the study. The study conducted from May 1st to October 71993 resulted in an intrinsic rate of increase per week of $r_{7}=1.13$. The study conducted from October 221993 to April 7 1994 resulted in an intrinsic rate of increase per week of $r_{7}=1.10$ (fig 2). Given these rates of increase, the mite population increased within 1 year by 576 -fold and 42 fold, respectively. Given an intrinsic rate of increase of $r_{7}=1.13$ during the summer 6 months and an intrinsic rate of increase of $r_{7}=1.10$ during the winter 6 months the mite population increases 286 -fold within 1 year.

\section{Comparison of natural death rate and calculated population size}

Natural death rate during the first 4 months of the study suggests slower population growth than the calculation based on $r_{7}$. During the fifth month of the study natural death rate indicates a faster population growth than the calculation based on $r_{7}$ (fig 2).

\section{Effect of Apistan ${ }^{\circledast}$ residues in wax on $\mathrm{V}$ jacobsoni}

At the end of the study conducted from September 1993 to April 1994, colonies that contained combs with direct contact with Apistan ${ }^{\circledast}$ prior to reinnoculation with mites contained an average of $403 \pm 50$ mites (range $=352-453, n=2$ ). Colonies without combs exposed to Apistan ${ }^{\circledR}$ contained an average number of $1268 \pm 316$ SE mites (range $=854-1620, n=4$ ). Colonies exposed to combs containing residues of fluvalinate (active compound of Apistan ${ }^{\circledR}$ )

average numbers of Varroa mites per monitor colony per week

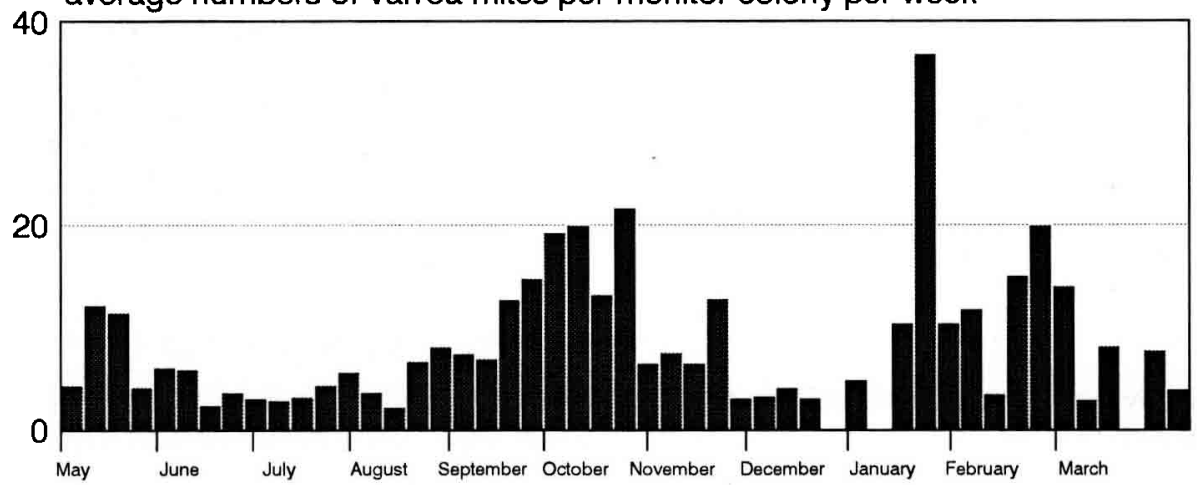

Fig 1. Numbers of Varroa mites invading 5 monitor colonies placed among artifically inoculated test colonies. Monitor period: start inoculation May 11993 (summer); end Apistan ${ }^{(1)}$ treatment April 71994 (winter). 


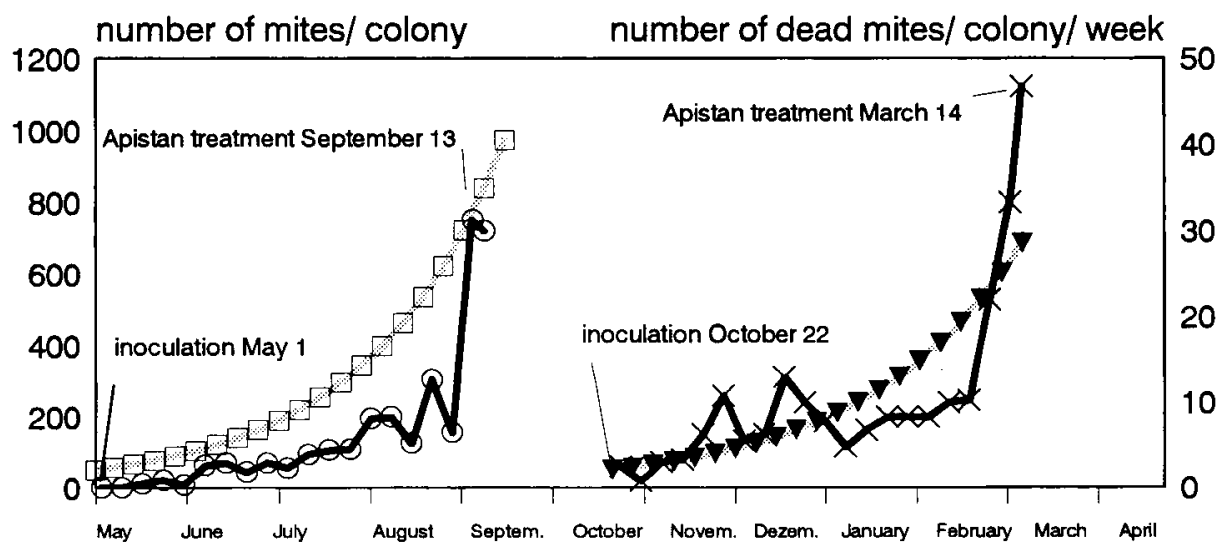

Fig 2. Natural Varroa death rate in colonies inoculated with 50 mites each and Varroa population size calculated on the basis of constant reproduction of mites. Series 1: (circle, solid line, ordinate 2): average number of dead Varroa mites per colony per week $(n=21)$. Series 2 : (square, broken line, ordinate 1) : average number of Varroa mites per colony calculated based on 1.16-fold increase of the mite population within $7 \mathrm{~d}$. Invading mites are not taken in account. Series 3: (cross, solid line, ordinate 2): average number of dead Varroa mites per colony per week $(n=4)$. Series 4: (wedge, broken line, ordinate 1): average number of Varroa mites per colony calculated based on 1.14-fold increase of the mite population within $7 \mathrm{~d}$. Invading mites are not taken in account.

contained on average $68 \%$ fewer $V$ jacobsoni than colonies that did not contain contaminated combs.

\section{Effect of colony strength}

No clear correlation between number of bees, amount of brood, ratio of bees per brood, amount of honey, amount of pollen and levels of Varroa mite infestation was found (Spearman rank correlation coefficient: $r_{s}=0.199,0.216,0.028,0.060,0.292$; $\alpha>0.5$ ).

\section{DISCUSSION}

The data presented show that population size of $V$ jacobsoni in infested honey-bee colonies increases in California at least 30 times faster than previously reported from countries with more temperate climates (Ritter, 1984). It is likely that this is rather an underestimate. The reproduction of $V$ jacobsoni was underestimated as the calculations were based on the assumption that all mites invading colonies contribute to size of the Varroa population. However, this assumption is only true if all the mites that invaded monitor colonies are mites imported from colonies other than the test colonies. Probably a substantial portion of mites that invaded the monitor colonies originated from test colonies and, therefore, did not add to total population growth within test colonies. Reproduction of $V$ jacobsoni was further underestimated because a high proportion of mites was killed at the beginning of the final Apistan ${ }^{\circledR}$ treatment and, therefore, excluded from reproduction for the duration of the 4 treatment weeks. Reproduction of $V$ jacobsoni was slightly overestimated by adding the number of mites that invaded monitor colonies within a $7-d$ period to the mite population only at the end of this period. Reproduction of the immigrant mites was not considered during that period. 
Even in cold climates, the numbers of mites can increase in an infested colony up to 100-fold within one summer (Fries et al, 1991). In temperate and cold climates, broodless periods interrupt the mites' reproduction and the mite population declines during winter (Ritter, 1984; Fries et al, 1991; Korpela et al, 1992). We also found high reproduction rates during the winter in California. Fast population growth of the parasite in Mediterranean climates is, therefore, obviously not caused by fast population growth during summer. The main factor causing rapid population growth of the Varroa population in honey-bee colonies located in Mediterranean climates is probably the nearly constant presence of brood. It is unlikely that the high virulence of $V$ jacobsoni in California might be related to its recent introduction with no time for host-parasite adaptation. Even in European countries where $V$ jacobsoni was detected in the 1970 s, no signs of adaptation of either host or parasite towards a more balanced relationship have developed. Delfinado-Baker and Houck (1989) suggested a lower virulence of mites from North America compared to mites from Europe, based on the probable South American origin of mites in the USA. However, this has been proven wrong by the present study. The population growth of the parasite forces Californian beekeepers to apply measures of Varroa control colonies in the fall and the spring. Beekeepers located in countries with more temperate or cold climates usually only treat colonies with pesticides in the fall. In Israel, with a Mediterranean climate, 1 treatment per year also proved to be insufficient (Lubinevski et al, 1988).

A calculation of population growth of Varroa mite populations in infested colonies conducted by Calatayud and Verdu (1993) by means of natural death rate led to results comparable to results of the present study ( $r=0.027$ per day compared to $r=0.021$ per day during summer in the present study). However, population growth calculated on the basis of the assumption of constant reproduction and population growth indicated by natural death rate is not highly correlated in the present study. This might be caused by seasonal differences in reproduction rate, seasonal deviations in natural death rate and other factors which make it difficult to calculate the size of Varroa populations based on natural death rate (Fuchs and Koeniger, 1984; Liebig et al, 1984; Maul, 1984; Rademacher, 1985). In previous studies, reproduction of $V$ jacobsoni was found to be influenced by the total number of brood cells per colony and by the number of brood cells per bee (Otten, 1991). In the present study no significant correlation was found. Colony estimates were only conducted in October and correlations between the size of the mite population and the number of brood cells per colony and the number of brood cells per bee may be more pronounced during the summer or early fall.

The previously described effect of Apis$\tan ^{\circledR}$ upon $V$ jacobsoni occurring after termination of the treatment (Moosbeckhofer, 1991) was confirmed. Mites in such situations are obviously constantly exposed to considerable amounts of fluvalinate residues in wax and are, therefore, constantly selected for pesticide resistance.

\section{ACKNOWLEDGMENTS}

We thank $\mathrm{K}$ Fondrk for his continuous technical support. We thank S Fuchs for critically reading and substantially improving the manuscript. This study was made possible by the Deutsche Forschungsgemeinschaft (grant Kr 1275/1-2), the California State Beekeepers' Association, and CDFA contracts 92-0418 and 92-0615.

Résumé - La dynamique des populations de Varroa jacobsoni Oud sous le climat méditerranéen de Californie. Le climat influe sur la croissance des popula- 
tions de Varroa jacobsoni, parasite de l'abeille mellifère (Ritter et De Jong, 1984 ; De Jong et al, 1984 ; Moretto et al, 1991 ; etc). Dans les régions à climat méditerranéen, une croissance rapide des populations, ainsi qu'une virulence élevée, ont été mises en évidence (Frilli, 1989 ; Lubinevski et al, 1988) mais n'a jamais été précisément quantifiée. Notre étude vise à déterminer la dynamique des populations de $V$ jacobsoni en Californie centrale (climat méditerranéen), un an après le début de pertes massives de colonies causées par le parasite. Pour cela des colonies d'abeilles (Apis mellifera ligustica) traitées à l'Apis$\tan ^{\circledR}$ ont été infestées le $1^{\text {er }}$ mai 1993 (21 colonies) et le 22 octobre 1993 ( 6 colonies) avec 50 varroas chacune. La mortalité naturelle et l'invasion des acariens dans 5 colonies traitées continuellement à l'Apistan ${ }^{(B)}$ ont été relevées chaque semaine. Vingtquatre sem plus tard (13 septembre 1993 et 10 mars 1994) les populations de varroas présentes dans les colonies infestées ont été déterminées par un traitement à l'Apistan ${ }^{\circledR}$. À la fin de l'expérimentation faite en été il y avait en moyenne $1614 \pm 485$ acariens dans les colonies (écart = $690-2867, n=21$ ), et $1268 \pm 316$ (écart $=$ $854-1620, n=4$ ) à la fin de celle d'hiver. Cela correspond à une augmentation de la population $R_{7}$ de 1,16 fois en été et de 1,14 fois en hiver. On a essayé d'évaluer l'impact du transfert de nouveaux varroas sur la croissance de la population. Si on admet pour le calcul de $R_{7}$ que tous les transferts d'acariens se sont faits à partir de colonies non prises en compte dans l'étude, on obtient un facteur $R_{7}$ de 1,13 en été et de 1,10 en hiver. Selon ce calcul de $R_{7}$ la population de varroas dans les colonies infestées augmente de 286 fois par an. En climat tempéré la population n'est multipliée que par 10 chaque année. La croissance rapide du parasite en climat méditerranéen n'est pas due à un taux de reproduction plus élevé mais à la possibilité de se reproduire continuellement dans le couvain qui est pré- sent presque toute l'année. En revanche, en climat tempéré et en climat froid, la reproduction de $V$ jacobsoni s'interrompt pendant les périodes où il n'y a pas de couvain (Ritter, 1984 ; Fries et al, 1991 ; Korpela et al, 1992). Aucune corrélation significative n'a été trouvée entre le nombre d'abeilles, la surface de couvain, le rapport abeilles/couvain ou les quantités de miel et de pollen avec le niveau d'infestation par $V$ jacobsoni. Avant l'infestation provoquée en octobre 1993 les rayons de 4 colonies, qui avaient été en contact avec des lanières d'Apistan ${ }^{\circledR}$, ont été remplacés par des rayons dépourvus de résidus. Dans 2 colonies, où ils n'avaient pas été remplacés, les varroas étaient $68,2 \%$ moins nombreux à la fin de l'expérience que dans les colonies qui ne renfermaient que des rayons dépourvus de résidus. Ce résultat confirme celui de Moosbeckhofer (1991) : les résidus de fluvalinate dans la cire exercent une action sur $V$ jacobsoni. Selon Delfinado-Baker et Houck (1989) $V$ jacobsonia pu être importé d'Amérique du Sud en Amérique du Nord par des abeilles africanisées et serait en conséquence moins virulent aux États-Unis qu'en Europe. Notre étude infirme cet espoir. Les apiculteurs californiens sont contraints par la croissance rapide des populations de $V$ jacobsoni à traiter leurs ruches 2 fois par an avec une méthode efficace. En climat froid ou tempéré un traitement à l'automne suffit.

Varroa jacobsoni / dynamique population / virulence / climat méditerranéen / Californie Zusammenfassung - Das Populations-
wachstum von Varroa jacobsoni im
mediterranen Klima von Kalifornien. Das
Populationswachstum des Bienenparasiten
Varroa jacobsoni Oud wird von Klimafakto-
ren beeinflußt (Ritter und De Jong, 1984;
De Jong et al, 1984, Moretto et al, 1991).
In Ländern mit mediterranem Klima wurde 
ein schnelles Populationswachstum und damit eine hohe Virulenz des Parasiten festgestellt (Lubinevski et al, 1988; Frilli, 1989), jedoch nicht näher quantifiziert. In der vorliegenden Studie sollte die Frage nach dem Populationswachstum von $V$ jacobsoni im mediterranen Klima Zentralkaliforniens ein Jahr nach dem ersten Auftreten von durch den Parasiten verursachter Völkerzusammenbrüchen beantwortet werden. Hierzu wurden mit dem Varroazid Apistan ${ }^{\circledR}$ behandelte Bienenvölker (Apis mellifera ligustica) am 1. Mai 1993 (21 Völker) sowie am 22. Oktober 1993 (6 Völker) mit jeweils 50 Milben infiziert. Es erfolgte eine wöchentliche Kontrolle des natürlichen Totenfalles sowie der Milbeninvasion in fünf permanent mit Apistan ${ }^{(B)}$ behandelten Monitorvölkern. Ab dem 13.September 1993 sowie dem 10. März 1994 wurde die in den infizierten Völkern befindliche Varroapopulation durch eine Apistan ${ }^{\circledR}$ behandlung bestimmt. Am Ende der während des Sommerhalbjahres durchgeführten Studie befanden sich im Durchschnitt $1614 \pm 485$ SE (Spanne = 690-2867, $n=21$ ) Milben in den Völkern, am Ende der während des Winterhalbjahres durchgeführten Studie im Durchschnitt 1268 \pm 316 SE (Spanne $=854-1620, n=4$ ) Milben. Daraus ergibt sich eine wöchentliche Zunahme der Population $r_{7}$ um das 1,16fache im Sommer und 1,14-fache im Winter. Es wurde versucht, den Einfluß der Invasion durch zusätzliche Milben abzuschätzen. Geht man bei der Berechnung von $r_{7}$ von der Annahme aus, daß der Milbentransfer ausschließlich von nicht in den Versuch integrierten Völkern in Versuchsvölker hinein erfolgte, so ergibt sich ein Faktor $r_{7}$ von 1,13 in Sommer und 1,10 im Winter. Diese sehr konservative Berechnung von $r_{7}$ ergibt eine Zunahme der Varroapopulation in infizierten Völkern um das 286-fache pro Jahr. In gemäßigten Klimaten nimmt die Varroapopulation lediglich um das etwa 10fache pro Jahr zu (Ritter, 1984). Das schnelle Populationswachstum des Para- siten in mediterranen Ländern wird nicht durch eine höhere Reproduktionsrate verursacht, sondern durch die ständige Möglichkeit zur Reproduktion in der fast permanent vorhandenen Bienenbrut. In temperaten und kalten Klimaten hingegen wird die Reproduktion von $V$ jacobsoni durch brutlose Perioden unterbrochen (Ritter, 1984; Fries et al, 1991; Korpela et al, 1992). In der vorliegenden Studie waren bei einer im Oktober 1993 durchgeführten Schätzung der Anzahl Bienen, der Brutfläche, der Honigmenge und der Pollenmenge weder einer dieser Parameter noch der Koeffizient Anzah/ Bienen/ Brutfläche signifikant mit der Anzahl Milben im Volk korreliert. Vor der im Oktober 1993 durchgeführten Infektion mit $V$ jacobsoni wurden bei vier Völkern Waben, die zuvor Kontakt mit Apistan ${ }^{\circledR}$ streifen hatten, gegen rückstandsfreie Waben ausgetauscht. Bei zwei Völkern erfolgte kein Austausch von Waben. In diesen Völkern befanden sich zu Versuchsende 68,2\% weniger Milben als in den Völkern, die ausschließlich rückstandsfreie Waben enthielten. Dieses Ergebnis bestätigt den von Moosbeckhofer (1991) beschriebenen Effekt von im Wachs befindlichen Fluvalinatrückständen auf $V$ jacobsoni. Delfinado-Baker und Houck (1989) beschrieben die Möglichkeit, daß $V$ jacobsoni durch afrikanisierte Bienen von Südamerika aus nach Nordamerika importiert wurde und daher in den USA weniger virulent sei als in Europa. Die vorliegende Studie zeigt, daß diese Hoffnung sich nicht erfüllt hat. Kalifornische Imker sind durch das schnelle Populationswachstum von $V$ jacobsoni gezwungen, ihre Völker zweimal pro Jahr mit einer effektiven Methode zu behandeln. In temperaten oder kalten Klimaten ist eine Behandlung im Herbst im allgemeinen ausreichend.

Varroa jacobsoni / Populationswachstum / mediterranes Klima / Virulenz / Kalifornien 


\section{REFERENCES}

Büchler R (1990) Genetisch bedingte Unterschiede in der Anfälligkeit von Bienenvölkern (Apis mellifera $\mathrm{L}$ ) gegenüber der Varroa-Milbe (Varroa jacobsoniOud) als Grundlage einer Zucht auf erhöhte Widerstandsfähigkeit. Ph D Thesis, Friedrich-Wilhelms, Universität Bonn, Germany

Calatayud F, Verdú MJ (1993) Hive debris counts in honey bee colonies: a method to estimate the size of small populations and rate of growth of the mite Varroa jacobsoni Oud (Mesostigmata: Varroidae). Exp Appl Acarol 17, 889-894

Carey JR (1993) Applied Demography for Biologists with Special Emphasis on Insects. Oxford University Press, New York, USA, $206 p$

De Jong D, Morse RA, Eickwort GC (1982) Mite pests of honey bees. Annu Rev Entomol 27, 229-252

De Jong D, Gonçalves LS, Morse R (1984) Dependence on climate of the virulence of Varroa jacobsoni. Bee World 65, 117-121

Delfinado-Baker M, Houck MA (1989) Geographic variation in Varroa jacobsoni (Acari, Varroidae): application of multivariate morphometric techniques. Apidologie 20, 345-358

Engels W, Gonçalves LS, Steiner J, Buriolla AH, Cavichio Issa MR (1986) Varroa-Befall von Carnica-Völkern in Tropenklima. Apidologie 17, 203-216

Fries I, Aarhus A, Hansen H, Korpela S (1991) Development of early infestations by the mite Varroa jacobsoni in honey-bee (Apis mellifera) colonies in cold climates. Exp App/ Acarol 11, 205-214

Frilli $F$ (1989) Varroatosis situation in Italy. In: Present Status of Varroatosis in Europe and Progress in the Mite Control (R Cavalloro, ed), Office for Publications of the European Communities, Brussels, Belgium, 37-38 $p$

Fuchs S, Koeniger N (1984) Rechnen oder Raten - das Dilemma bei der Abschätzung des Varroabefalles. Allg Dtsche Imkerztg 18, 294-296

Fuchs $S$ (1991) Kleine Volkseinheiten zur Bestimmung der Varroatoseanfälligkeit. Apidologie 22, 463-465

Gerig L (1983) Lehrgang zur Erfassung der Volksstärke. Schweiz Bienen-Ztg 106, 106, 99-204

Herbert, EW Jr, Witherell PC, Bruce WA, Mladjan VJ, Shimanuki $H$ (1989) Observations on Varroa-infested honey bee packages treated with Apistan ${ }^{\oplus}$ and hived. Am Bee J129, 799-801

Korpela S, Aarhus A, Fries I, Hansen $H(1992)$ Varroa jacobsoni Oud in cold climates: population growth, winter mortality and influence on the survival of honey bee colonies. J Apic Res 31, 157-164
Kraus $B$, Page RE Jr (1995) Effect of vegetable oil on Varroa jacobsoni Oud and honey bee colonies. Beescience (in press)

Kulincevic JM, Rinderer TE, Mladjan VJ, Buco SM (1992) Five years of bidirectional genetic selection for honey bees resistant and susceptible to Varroa jacobsoni. Apidologie 23, 399-402

Liebig G, Schlipf U, Fremuth W, Ludwig W (1984) Ergebnisse der Untersuchungen über die Befallsentwicklung der Varroa-Milbe in Stuttgart-Hohenheim 1983. Allg Dtsche Imkerztg 9, 185-191

Lubinevski Y, Stern Y, Slabezki Y, Lensky Y, Ben-Yossef $\mathrm{H}$, Gerson U (1988) Control of Varroa jacobsoni and Tropilaelaps clareae mites using Mavrik ${ }^{\mathrm{M}}$ in $\mathrm{A}$ melIifera colonies under subtropical and tropical climates. Am Bee J 128, 48-52

Maul V (1984) Abschätzen des Varroabefalls über den spontanen Milbenabfall. Apidologie 15, 243-244

Moosbeckhofer R (1991) Apistan und Bayvarol Langzeitwirkung behandelter Waben. Die Biene 127 , 331-334

Moretto G, Gonçalves LS, De Jong D, Bichutte MZ (1991) The effects of climate and bee race on Varroa jacobsoni Oud infestations in Brazil. Apidologie 22, 197-203

Moritz RFA, Hänel H (1984) Restricted development of the parasitic mite Varroa jacobsoni Oud in the cape honeybee, Apis capensis Esch. Z Angew Entomol $97,91-95$

Otten C (1991) Vergleichende Untersuchungen zum Populationswachstum von Varroa jacobsoni Oud. in Völkern von Apis mellifera $L$ unterschiedlicher geographischer Herkunft. Ph D Thesis, JW Goethe Universität Frankfurt, Germany

Rademacher E (1985) Ist eine Befallsprognose aus dem natürlichen Totenfall von Varroa jacobsoni möglich? Apidologie 16, 395-406

Ritter W (1984) Neuester Stand der diagnostischen und therapeutischen Massnahmen zur Bekämpfung der Varroatose. Tierärztliche Umschau 39 , 122-127

Ritter W, De Jong D (1984) Reproduction of Varroa jacobsoni Oud in Europe, the Middle East and tropical South America. $Z$ angew Entomol $98,55-57$

Rosenkranz P (1990) Wirtsfaktoren in der Steuerung der Reproduktion der parasitischen Bienenmilbe Varroa jacobsoni in den Völkern von Apis mellifera. Ph D Thesis Eberhard-Karls, Universität, Tübingen, Germany

Sakofski F, Koeniger N, Fuchs S (1990) Seasonality of honey bee colony invasion by Varroa jacobsoni Oud. Apidologie 21, 547-550 